\title{
Business model innovation for eco-efficiency: an empirical study
}

\author{
Yan $\mathrm{Li}^{1{ }^{1, *}, \text { Steve Evans }}{ }^{2}$ \\ ${ }^{1}$ University of Greenwich, Old Royal Naval College, Park Row, \\ London, UK SE10 9LS \\ ${ }^{2}$ Institute for Manufacturing. University of Cambridge \\ 17 Charles Babbage Road, Cambridge, UK CB3 OFS \\ yan.1i@gre.ac.uk; se321@cam.ac.uk
}

\begin{abstract}
Business model has the potential to create value and capture value for companies, which is critical for their sustainable development [1]. The concept of eco-efficiency can be a useful concept to link an enterprise's business with sustainable development as well as achieving long-term profits [2,3]. Extant literature reveals that there is a need to study business model innovation and ecoefficiency under one text to achieve a win-win rationale to increase profits while reducing environmental impact [4,5]. This empirical study conducted 8 -in-depth case studies with manufacturing companies across UK and China. The author synthesized the cases and concluded the measures of business model innovation for eco-efficiency in five categories, namely (1) Selling of service model, (2) Direct selling model, (3) Collaboration strategy, (4) Whole system design strategy, and (5) Technology renovation strategy. The empirical finding suggests the adaptation of strategy and exploitation of the technologies are essential to business model innovation when manufacturing companies seeking to implement eco-efficiency.
\end{abstract}

Keywords: Business model innovation; Eco-efficiency; Sustainable business model

\section{Introduction}

In order to achieve a profitable sustainable business, one possible solution for manufacturing industries is to innovate their current business model to generate more value, as well as increase eco-efficiency to reduce environmental impact [6]. For one thing, an effective business model links the strategic and technical potential, as well as delivering value to customers and generating profits for enterprises [6,7]. Additionally, the business model connects the workings inside the firm to outside elements including the customer side, and captures or monetizes value $[1,8]$. For another, improving a company's eco-efficiency, enterprises would improve their environmental factor that yields parallel economic benefits [3]. More importantly, eco-efficiency can reduce the environmental impact and natural resources, as well as maintaining or increasing the value of the output [9]. Therefore, linking to business strategies, eco- efficiency plays the role of eliminating risks and identifying new market opportunities, which is very attractive 
to companies [3]. However, through the literature review, it is apparent that the direct connection of business model and eco-efficiency is deficient, especially for the empirical cases to illustrate how companies adapt their business model to implement ecoefficiency.

The scope of this study focuses on business model innovation and eco-efficiency implementation at organisational level. The author seeks to determine how companies carry out eco-efficiency by means of business model innovation. Thereby, the research question is proposed 'How do manufacturing enterprises innovate their business model to realise eco-efficiency?' To answer the research question, an inductive multiple-case study is conducted. 8-in-depth cases across the UK and China are analysed comprehensively.

\section{$2 \quad$ Literature review}

2.1 Business model innovation

According to Björkdahl and Holmén (2013), business model innovation refers to creating or reinventing something new or different in doing business [10]. In other words, at least one constitution element of the current business model is changed [11]. Giesen et al. (2007) identified three main types of business model innovation, which are in industry models, in revenue models and in enterprise models [12]. They proved that each of the three types of business model innovation could lead to success. Among the three types, innovation in enterprise is the most popular, because it focuses on network plays (e.g. external collaborations, partnerships, etc.). At this stage, Velu (2014 p.2) explained that business model innovation can "redefine what a product or service is, how it is provided to the customer, and how it is monetized" [13]. Therefore, business model innovation can change the mode of competition through altering the performance metrics [14].

Foss and Saebi (2016) reviewed 150 publications and concluded that there were four streams of business model innovation [15]. The first stream emphasized the conceptualization of business model innovation $[1,16]$. This stream offers a clear definition of business model innovation and highlights the phenomenon itself. The second stream argues that business model innovation is an organisational change process and emphasizes the required capabilities $[17,18]$. The third stream argues that business model innovation is an outcome of the organisational change process. This stream often regards the emergence of new business in a particular industry such as electric mobility and aviation [15]. The fourth stream addresses the organisational performance implications of business model innovation. This stream differentiates the outcome influenced by the business model innovation process and the performance affected by different types of business model $[19,20]$.

\subsection{Eco-efficiency}


Eco-efficiency is an essential component of corporate social performance. It also acts as a forward-looking measure of the potential practicality, especially for both researchers and practitioners [21]. Mickwitz et al. (2006) illustrated that eco-efficiency is capable of reducing the environmental impact and natural resources, as well as maintaining or increasing the value of the output [9]. Thus, improving eco-efficiency requires the production of more desirable outputs (GDP), while reducing the consumption of resources and adverse ecological impacts [22]. Yu et al. (2013) discussed that eco-efficiency is the main strategy for promoting sustainability through living within the global resource-carrying capacity [23]. Eco-efficiency is also recognized as a significant tool to evaluate environmental and economic challenges at the same time [24]. Specifically, it indicates that a firm displays a good financial performance with less environmental impact or offers a high-quality product with added value [25].

Currently, eco-efficiency is widely accepted both for increasing economic value and reducing environmental effects [26]. It is an instrument for sustainability analysis, showing the empirical economic relationship between environmental cost or value and environmental input [9].

\section{$3 \quad$ Methods}

The aim of this research is to explore how do companies realise eco-efficiency by means of business model innovation. There exist two main activities in theory development, which is "the formulation of propositions" and "testing whether they can be supported" [27]. This research uses a qualitative case study to explore knowledge inductively [28]. Hence, this research is based on the exploration for theory to discover the strategies, which instructs practitioners identify their possible solutions to implement eco-efficiency effectively.

There are three justifications to select case study as the main research method. Firstly, case study is one of the most flexible methods, which provides a plenty of detailed description of a particular phenomenon [29]. Secondly, this research focuses on the contemporary event, which is identical to the conditions of case study method [30]. Thirdly, According to Eisenhardt (1989) and Hagg et al. (1979), many single-case are criticized, as they cannot provide any basis for generalization, while multi-case construct a stronger basis for knowledge building. This research is selected to use multiplecase study $[28,31]$.

The data collection method of the research is case study. Eight cases include 26 interviews are conducted. Interviewees are CEO, Strategic manager, and engineers. The following Table 1 presents the detailed list of interviews.

Since no previous literature illustrates how companies could innovate an effective business model in the drive towards eco-efficiency, the most suitable structure of this research is the theory building structure. Hence, the theory is built up from the real world 
and it is data-driven research. To conclude, inductive grounded theory is the most appropriate one for data analysis in this research.

Table 1 List of interviews

\begin{tabular}{|c|c|c|}
\hline $\begin{array}{c}\text { Com- } \\
\text { pany }\end{array}$ & $\begin{array}{c}\text { Core business } \\
\text { views) }\end{array}$ \\
\hline CC & Glass-recycling company & 4 \\
\hline GXA & $\begin{array}{c}\text { Large-scale equipment manufacturing enterprise } \\
\text { produces numerical machine tool parts; energy equip- } \\
\text { ment }\end{array}$ & 5 \\
\hline SGU & $\begin{array}{c}\text { Manufacturing blowers for either state-owned or } \\
\text { privately owned manufacturing industries in diverse } \\
\text { fields }\end{array}$ & 4 \\
\hline BJX & $\begin{array}{c}\text { Design mattresses and use the Original Equipment } \\
\text { Manufacturer (OEM) to produce }\end{array}$ & 2 \\
\hline RS & Start-up company producing hydrogen cars & 3 \\
\hline HT & Electric bike start-up company & 2 \\
\hline AB & $\begin{array}{c}\text { A 50-year history company in designing, manufac- } \\
\text { turing and delivering aerospace products, services and } \\
\text { solutions to customers globally }\end{array}$ & 2 \\
\hline Vit & Shelving and storage manufacturer and supplier & 4 \\
\hline
\end{tabular}

\section{$4 \quad$ Findings and Discussion}

\section{Selling of service model}

Conventionally, companies sell products to customers and encourage customers to buy new products consistently. In this business model, companies upgrade their new generation of products to make customers buy the latest one, although their previous products are still in a good, usable condition. In this context, companies will not pay much attention to the durability of their products. This is because, the more goods they sell, the more profits they make. Moreover, taking the customers' point of view, when they buy a new product, they do not have a proper channel to dispose of their old one. For instance, most customers would like to keep their old usable phones, since the trade-in price is not fair enough for a phone in a good condition. In this sense, customers are not able to recycle their products properly, which is a waste of materials and energy.

In contrast, in the innovated business model, companies retain the ownership of their products. They sell the usage of the product and service to customers. Customers pay the subscription fees or rental fees per month to have the right to obtain a new product when the old one has been used until the end of its life or when the new generation product has been released. This innovated business model encourages companies to increase the durability of their products, and companies naturally manufacture high- 
quality products to reduce maintenance costs. In addition, customers do not have to bother to dispose of the old product, since the companies will find the best way to recycle or reuse the product to maximize its value.

\section{Direct selling model}

Vit and HT's cases suggest that the 'Direct selling' business model can also be shaped to increase eco-efficiency and reduce the waste of resources. Vit changed their business model from distribution route to direct selling. Since there are no distributors or retailers, Vit's current product price is two times less than before. This innovated business model means that Vit distributes furniture directly to customers. In this sense, they can use suppliers' packaging to pack outgoing parts. They can also reuse wooden stillage, which is used to transport aluminium parts, for a period of around 20 years. This business model allows Vit to control the usage of resources. Otherwise, the distributors/retailers' route will inevitable use extra energy and space for storage and expenditure of extra materials for packaging.

Unlike Vit, HT started to use this 'Direct selling' business model since the company was founded. Hence, there is no data to make a comparison between the previous conventional distribution route and the innovated 'Direct selling' route. The interviewees emphasized that 'direct selling' makes their company understand their customers' requirements better. Also, since there is no distributor or retailer, companies can focus on helping suppliers to carry out eco-efficiency.

\section{Collaboration strategy}

The fundamental element of this strategy is to clearly recognize the company's status and the limitation of its resource capability. RS is specialized in participating in various projects. The company currently has eight ongoing projects collaborating with universities, research institutions and other companies. Different projects expand the business domain and generate opportunities for RS. Furthermore, their open-minded action allows the company to take the most advantage from other participants. For example, they can get eco-related consulting suggestions from university researchers and other institutes' consultants. They can also learn from other participating companies how they dispose of their waste and increase energy efficiency. CC's data suggests that collaboration helps to increase the public's cognition of eco-efficiency. As a leading glass recycling company in Taiwan, $\mathrm{CC}$ has a positive brand value. They recognized that their brand popularity attracts potential collaborators and the collaborators will in turn increase their brand popularity in a positive circle. More importantly, by means of collaboration, the public's awareness of recycling will be increased. Their brand will become more famous and their products will be more easily accepted by customers.

\section{Whole system design}

Upgrading the business strategy from the individual level to the 'whole system' level is one of the most eco-efficient measures that a company can take. Conventionally, companies consider individual components in a narrow perspective. The innovated 'whole system' view considers a product's economic and environmental performance 
throughout its life, which increase the usage from several years to a few decades. Taking the 'whole system' view, companies consider both the short-term and long-term views, and allocate resources (e.g. materials, energy, water) more effectively. For instance, AB changed their business model 'from architect to integrate'; they believe innovation is their key driving force. Hence, considering the whole system with a long vision, $\mathrm{AB}$ outsourced the production of several individual components to the OEM company. They concentrated on innovating the technology to design an eco-efficient aircraft. Moreover, HT, as a start-up company, built up a 'helicopter view' to design their electric bicycle. They looked at every single process through an eco-efficiency lens to increase productivity and save energy in production. For example, their folding bicycle design makes logistics easier both for supplier's distribution and customers' portability.

\section{Technology renovation strategy}

GXA's data suggests that upgrading technology is a key strategic revolution to improve eco-efficiency. For GXA, as a traditional casting manufacturing company, their traditional technique is to pour molten iron into a cavity with the required component dimensions moulded by sand. This technique produces enormous pollution. The working atmosphere is hazardous for operators. The company developed a $3 \mathrm{D}$ printing technique to print components directly, which has replaced the moulding and iron-pouring procedure. This new technique has increased their production efficiency by five times the previous rate. However, since the materials' challenge has not been fully conquered, this $3 \mathrm{D}$ printing manufacturing technique is still undergoing development.

\section{Concluding remarks}

The empirical research contributes practical implications for professional practitioners in industry. The empirical cases identified the status of the leading eco-efficient companies and their measures to induct eco-efficiency. The author synthesizes the cases and concludes the measures as five categories, namely: (1) Selling of service model, (2) Direct selling model, (3) Collaboration strategy, (4) Whole system design strategy, and (5) Technology renovation strategy. This finding confirmed the existing literature identifying that business model innovation generates value for companies. This study contributes to how adaptation of strategy and business model innovation can be made, when manufacturing companies seek to implement eco-efficiency.

The limitation of this research is the eco-efficiency research mainly based on strategic level. The techniques and measurements to improve eco-efficiency are not covered. In this sense, further research is suggested to extend technical data to the measures of ecoefficiency implementation. 


\section{$6 \quad$ Reference}

1. Teece, D. J. (2010) Business models, business strategy and innovation, Long Range Planning. Elsevier Ltd, 43(2-3), pp. 172-194. doi: 10.1016/j.lrp.2009.07.003.

2. Schaltegger, S., Sturm, A., (1990) Ökologische Rationalität (Ecologic Rationality). Unternehm 4, 273e290.

3. Madden, K., Young, R., Brady, K., Hall, J. (2005) Eco-efficiency: Learning Module. World Business Council for Sustainable Development (WBCSD), File Winds International.

4. Côté, R., Booth, A. and Louis, B. (2006) Eco-efficiency and SMEs in Nova Scotia, Canada, Journal of Cleaner Production, 14(6-7), pp. 542-550. doi: 10.1016/j.jclepro.2005.07.004.

5. Kabongo, J. D. and Boiral, O. (2017) Doing More with Less: Building Dynamic Capabilities for Eco-Efficiency, Business Strategy and the Environment, 26(7), pp. 956-971. doi: $10.1002 /$ bse. 1958 .

6. Chesbrough, H. and Rosenbloom, R. S. (2002) The role of the business model in capturing value from innovation: evidence from Xerox Corporation's technology spin-off companies, Industrial and Corporate Change, 11(3), pp. 529-555. doi: 10.1093/icc/11.3.529.

7. Lüdeke- Freund, F. (2010) Towards a Conceptual Framework of Business Models for Sustainability, Knowledge Collaboration and Learning for Sustainable Innovation ERSCPEMSU conference, Delft, The Netherlands, 49(0), pp. 1-28.

8. Amit, R., and C. Zott. (2001) Value creation in E-Business, Strategic Management Journal, 22 , no.6, pp.493-520.

9. Mickwitz, P., Melanen, M., Rosenström, U., Seppälä, J. (2006) Regional eco-efficiency indicators: a participatory approach. Journal of Cleaner Production 14, 1603-1611.

10. Björkdahl, J. and Holmén, M. (2013) Editorial: business model innovation - the challenges ahead, International Journal of Product Development, Vol. 18, No. 3, p.213.

11. Eurich, M., Weiblen, T. and Breitenmoser, P. (2014) A Six-Step Approach to Business Model Innovation, International Journal of Entrepreneurship and Innovation Management, 18(4), pp. 330-348. doi: 10.1504/IJEIM.2014.064213.

12. Giesen, E., Berman, S. J., Bell, R., and Blitz, A. (2007) Three ways to successfully innovate your business model. Strategy and Leadership, 35(6): 27-33.

13. Velu Chander and Jacob Arun, (2014) Business model innovation and owner-managers: the moderating role of competition. R\&D Management.

14. Daneels, E. (2004) Disruptive technology reconsidered: a critique and research agenda. Journal of Product Inno- vation Management, 21, 246-258.

15. Foss, N. J. and Saebi, T. (2016) Fifteen Years of Research on Business Model Innovation: How Far Have We Come, and Where Should We Go?, Journal of Management, 43(1), pp. 200-227. doi: 10.1177/0149206316675927.

16. Amit, R., and Zott, C. (2012) Creating Value Through Business Model Innovation Strategy in Changing Markets: New Business Models.

17. Pynnonen, M., Hallikas, J., and Ritala, P. (2012) Managing customer-driven business model innovation. International Journal of Innovation Management, 16: 1-18.

18. Achtenhagen, L., Melin, L., and Naldi, L. (2013) Dynamics of business models—strategizing, critical capabilities and activities for sustained value creation. Long Range Planning, 46: 427-442.

19. Bock, A. J., Opsahl, T., George, G., and Gann, D. M. (2012) The effects of culture and structure on strategic flexibility during business model innovation. Journal of Management Studies, 49: 279-305. 
20. Zott, C., and Amit, R. (2007) Business model design and the performance of entrepreneurial firms. Organisation Science, 18: 181-199.

21. Guenster, Nadja and Bauer, Rob and Derwall, Jeroen and Koedijk, Kees C. G. (2011) The Economic Value of Corporate Eco-Efficiency. European Financial Management, Vol. 17, Issue 4, pp. 679-704, 2011.

22. Huang, J. et al. (2014) A comprehensive eco-efficiency model and dynamics of regional eco-efficiency in China, Journal of Cleaner Production, 67, pp. 228-238. doi: 10.1016/j.jclepro.2013.12.003.

23. Yu, Y.D.; Chen, D.J.; Zhu, B.; Hu, S.Y. (2013) Eco-efficiency trends in china, 1978-2010: Decoupling environmental pressure from economic growth. Ecol. Indic. 24, 177-184.

24. Remigio, Helena and Govindan, Kannan and Azevedo, Susana and Cruz-Machado, Virgilio. (2017) Modelling green and lean supply chains: An eco-efficiency perspective. Resources, Conservation and Recycling. 120. 10.1016/j.resconrec.2016.09.025.

25. Nikolaou, I. E. and Matrakoukas, S. I. (2016) A framework to measure eco-efficiency performance of firms through EMAS reports, Sustainable Production and Consumption. Elsevier B.V., 8(June), pp. 32-44. doi: 10.1016/j.spc.2016.06.003.

26. Suh, Y. et al. (2014) Eco-efficiency Based on Social Performance and its Relationship with Financial Performance, Journal of Industrial Ecology, 18(6), pp. 909-919. doi: $10.1111 /$ jiec. 12167.

27. Dul, J., \& Hak, T. (2008). Case Study Methodology in Business Research. New York (Vol. 129).

28. Eisehardt, M., 1989. Building theories from case study research. The Academy of Management Review, 14(4), pp.532-550.

29. Hakin, C. 2000. Research Design: Succesful Designs for Social Economics Research: Routledge.

30. Yin, Robert K.(2014): Case Study Research . Design and Methods. 5th edition. Zeitschrift Für Personalforschung, 26(1), 93-96.

31. Hagg, I. and Hbdlund, G. (1979). Case studies in Accounting Research, Accounting, Organization and Scoiety, 4(I/2), 135-143. 